\title{
Performance of Exchange-Traded Funds in India
}

\author{
P. Krishna Prasanna ${ }^{1}$ \\ ${ }^{1}$ Department of Management Studies, Indian Institute of Technology, Madras, India \\ Correspondence: P. Krishna Prasanna, Department of Management Studies, Indian Institute of Technology, \\ Madras, 600036, Chennai, India. Tel: 91-442-257-4571. E-mail: pkp@iitm.ac.in
}

Received: October17, 2012

Accepted: November 5, 2012

Online Published: November 15, 2012

doi:10.5539/ijbm.v7n23p122

URL: http://dx.doi.org/10.5539/ijbm.v7n23p122

\begin{abstract}
The concept of Exchange-Traded Funds (ETFs) is very popular in foreign countries, but in India, it is still in the initial growth phase. This research paper examines the characteristics and growth pattern of all the 82 exchange traded schemes floated and traded on Indian Stock markets, and evaluates their performance using Data Envelopment Analysis (DEA). On an average, ETFs grew at 37\% annually during the period $2006-2011$ in India. These funds consistently outperformed the market index and generated higher returns. ETFs generated excess returns of 3\% p.a. as against CNX NIFTY, which is the Indian equity market bench mark. Gold ETFs provided $13 \%$ excess returns as compared to the returns on the equity market and attracted large investments in the post financial crisis years. Data Envelopment Analysis ranked domestic and overseas fund of funds as efficient funds, which were floated by foreign Asset Management Companies (AMCs) and the AMCs with Joint Ventures in India. Among the foreign AMCs, Franklin Templeton was found to offer the most efficient fund. These efficient funds are found to have higher Sharpe ratios, indicating that the DEA ranking is in broad consensus with the evaluation done using Sharpe ratios. However large funds were not found to be efficient funds. This infers that the fund size does not indicate superior performance.
\end{abstract}

Keywords: exchange-traded funds, data envelopment analysis, market index

\section{Introduction}

Exchange-Traded Funds (ETFs) were first introduced in USA in 1993. About $60 \%$ of trading volumes on the American Stock Exchange are reported to be from ETFs. As per the ETF landscape report released by BlackRock Inc. (a US-based AMC), ETFs have grown by $33.2 \%$, compounded annually in the past 10 years, and $26.1 \%$ in the past five years, globally.

ETFs are referred to as passive schemes that fund managers resort to, to avoid risk and offer low-cost options to the investors. These funds rely on an arbitrage mechanism to maintain the prices at which they trade, in line with the net asset values of their underlying portfolios.

As Exchange-Traded Funds started growing in India since 2006, the investment industry required performance analysis of this newly available financial asset. Moreover, fund selection also requires investors to analyze returns, volatility and performance of the available funds. The purpose of this paper is to empirically assess the investment performance of Exchange-Traded Funds in India. The paper uses monthly returns of ETFs over the period 2006-20011 to analyze 82 ETFs that were floated and traded on the Indian Stock Market across various themes. The paper investigates the relationship between fund size and performance and provides useful insights for the fund managers and investors.

Performance of ETFs has been examined on the basis of their returns and risk characteristics. Performance measures include average annual returns and excess returns measured by alpha values; risks measured by standard deviation and risk-adjusted returns measured by the Sharpe ratio. Data Envelopment Analysis (DEA) with three inputs and two out variables was used to analyze ETF performance and generate relative efficiency ranking among the peer group of funds.

On an average in India, ETFs grew at 37\% annually during $2006-2011$. These funds also generated excess returns of 3\% p.a. as against CNX NIFTY, the Indian equity market's bench mark. Gold ETFs provided 13\% excess returns as compared to the returns on the equity market and attracted large investments in the post financial crisis years. Data Envelopment Analysis ranked domestic and overseas fund of funds as efficient funds. These efficient funds were floated by foreign Asset Management Companies (AMCs) and the AMCs with joint 
ventures in India. In India, as on $31^{\text {st }}$ May 2011, there are 25 large funds which represent the most recent gold funds as well as overseas fund of funds. The efficient funds were not found to be the large funds; however, they offered higher returns and have higher Sharpe ratios.

This paper, being the first research work on ETFs in India, not only contributes to academic literature but also provides insights to investment professionals about an economy that is gaining significant prominence as an emerging economy in the global investment landscape.

\section{Exchange Traded Funds in India}

While the concept of ETFs is very much popular in foreign countries, in the Indian markets it is still in the initial growth phase. According to the Association of Mutual Funds of India (AMFI) data, the Indian mutual fund (MF) industry has been holding Rs. 6.75 trillion worth of assets over the past decade. On an average, during 2006-2011, Indian ETFs comprised of only $1.4 \%$ of the total industry assets. In comparison, in the US, ETFs comprise about $9 \%$ of the MF industry. This trend often raises the query among the investors as to whether or not Exchange-Traded Funds (ETFs) will be able to perform well in India.

In 2001, Benchmark was the first company to launch the first ETF in India - Nifty BeES, which was listed on the NSE for trade. In 2007, Benchmark also launched the first Gold Exchange-Traded Fund. Figure 1 presents a comparison of the growth in the total assets of the Indian MF industry and the growth of ETFs in India. The growth rate in ETFs was found to be higher than the industry growth rate during 2006 - 07. However, ETFs did not continue to grow at that pace in the post financial crisis period. Figure 2 presents the percentage of ETF assets with respect to the total assets of the Indian MF industry. While in 2006-07, the share of ETFs in the total industry was about $3 \%$, it fell subsequently and the average is around $1.4 \%$.

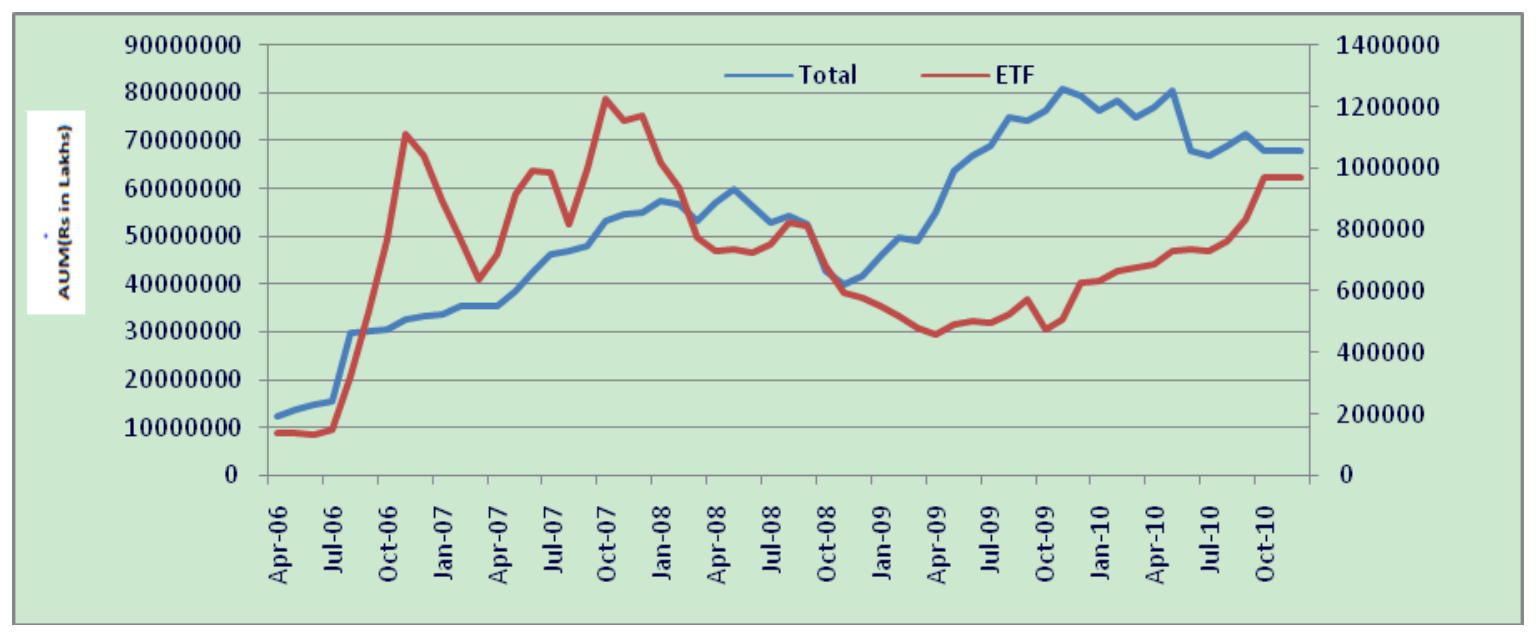

Figure 1. Comparative analysis of ETFs vs total funds 


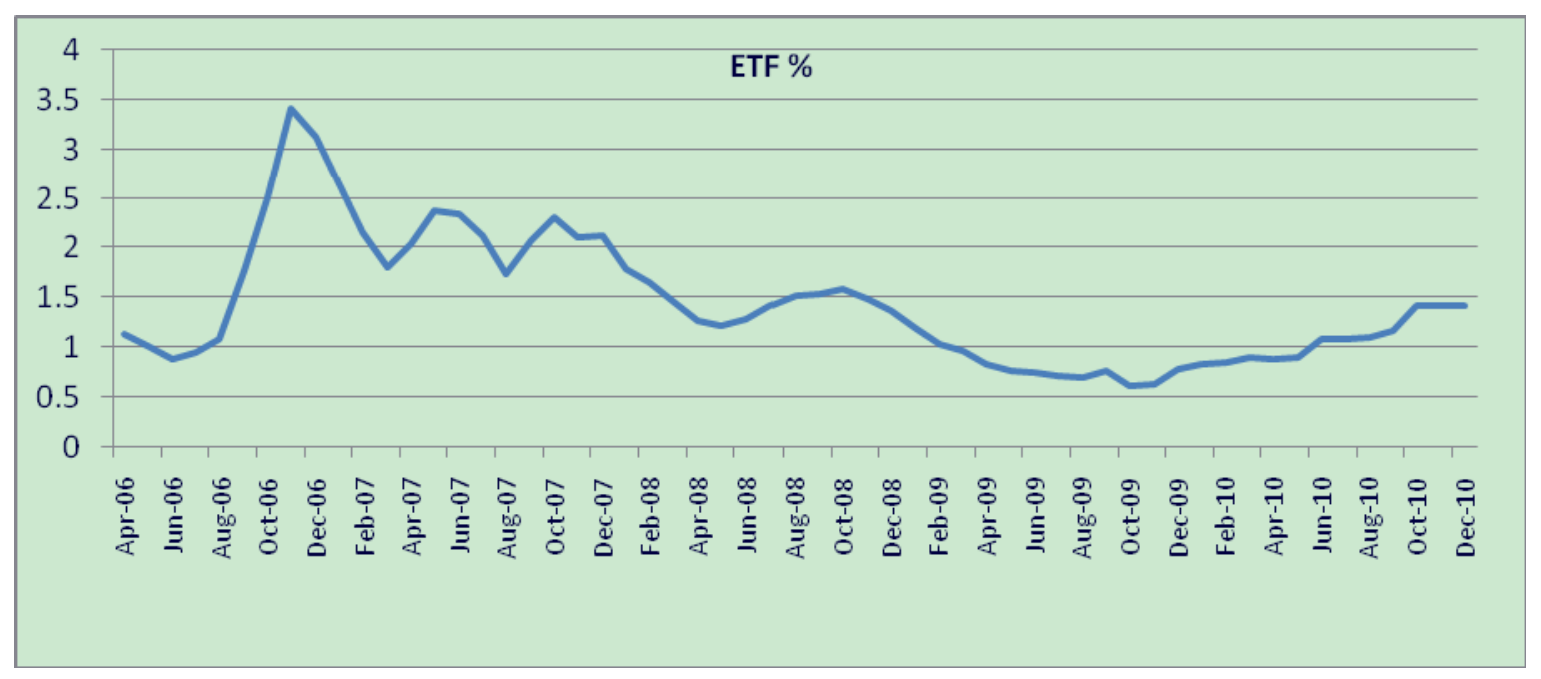

Figure 2. ETFs\% in the total Indian mutual fund industry

AMFI categorizes ETFs in India into 4 categories: i) Fund of funds oversees (FOF Overseas); ii) Fund of funds domestic (FOF Domestic); iii) Gold ETFs; iv) Other ETFs. The fund of funds schemes invest in a collection of mutual funds on the basis of an underlying theme. The most popular themes referred by AMCs in India are aggressive, conservative and moderate growth plans. The overseas fund of funds schemes collect money from domestic investors and invest it in global mutual funds as per some underlying theme. In India, the existing overseas fund of funds invests in themes such as agriculture, mining and emerging markets. Retail investors account for $94 \%$ of the folios for overseas fund of funds. It is expected that they would deliver super-normal returns. Gold ETFs invest in underlying gold markets. Other funds comprise of index funds in India, the underlying being popular and widely traded indices such as BSE Senses, CNX NIFTY or Bank NIFTY.

In this context this research paper investigates the performance of various categories of ETFs in India and addresses the following specific research objectives:

- To assess the growth rates and returns across the different categories of ETFs floated in India during the period 2005-2011.

- To examine whether ETFs provide excess returns to investors compared to CNX NIFTY, the equity market benchmark in India.

- To evaluate and rank various categories of Exchange-Traded funds to further explore:

$\circ$ Which categories of the funds (FOF/FOFO/GF/OF) are found efficient?

- Which AMCs were floating the efficient ETFs in India?

○ Does a higher Sharpe ratio indicate superior and consistence performance of a mutual fund?

- Do fund size and resultant higher growth rates indicate efficiency of the fund?

\section{Review of Literature}

\subsection{ETFs' Performance Across Countries}

The existing evidence in the literature on performance of ETFs is mixed. While there were many papers reporting negative performance of ETFs, there were others that presented strong positive evidence about the performance of ETFs.

Adjei Frederick (2009) found no significant difference between the performances of the ETFs and the S\&P 500 index. He found weak evidence of performance persistence on both the half-yearly and the yearly horizons. Johnson (2009) reported the existence of tracking errors between foreign ETFs and the underlying home index returns. Blitz David et al. (2010) investigated the performance of index mutual funds and the ETFs that are listed in Europe. They found that European index funds and ETFs underperform their benchmarks by 50 to 150 basis points per annum. William (2009) found the existence of tracking errors between foreign ETFs and the underlying home index in US. 
Blitz David and Huij (2011) evaluated the performance of ETFs that provide passive exposure to global emerging markets (GEM) equities and found that GEM ETFs exhibit higher tracking error. Houweling (2011) found that treasury ETFs were able to track their benchmark but investment grade corporate bond ETFs and high yield corporate bond ETFs underperform their benchmarks. Charupat \& Miu (2011) analyzed the performance of leverage ETFs, and concluded that price deviations are small among leverage ETFs and that price volatility is more, as a result of rebalancing, at the end of the day.

Patrick (2011) found that in Hong Kong the magnitude of tracking errors is negatively related to the size but positively related to the expense ratio of the ETFs. He further commented that replicating the performance of underlying securities involves more risk, since they have a higher tracking error than in the US and Australia.

Chang and Krueger (2012) investigated the performance of Exchange-Traded Funds and Closed-End Funds over the 2002 to 2011 period. They studied investment results such as returns, risks and risk-adjusted returns and found that though ETFs have significantly lower expenses, their performance is statistically worse than those of close-ended funds.

On the contrary, there was equal evidence of positive performance of ETFs. Ching-Chung et.al. (2005) indicated that the Taiwanese ETF and, the Taiwan Top 50 Tracker Fund (TTT) are price efficient and trading on them produces almost identical returns to the Taiwan stock market. Joel et al. (2006) compared the risk and return performances of ETFs available for foreign markets and closed-end country funds. They found higher mean returns and Sharpe ratios for ETFs, and concluded that a passive investment strategy through ETFs is observed to be superior to an active investment strategy using closely held country funds.

Huang and Guedj (2009) investigated as to whether an Exchange-Traded Fund (ETF) is a more efficient indexing vehicle than an Open-Ended Mutual Fund (OEF). They noted that ETFs are better suited for narrower and less liquid underlying indexes, and also for investors with long investment horizons. Jack et al. (2009) indicated that the US ETFs are more likely to trade at a premium than at a discount, with comparatively large daily price fluctuations. Gerasimos (2011) found that ETFs trade at a premium from their Net Asset Value (NAV) and the pattern of their returns can be predicted.

Meric et al. (2009) reported that from October 9, 2007 to March 9, 2009, the U.S. stock market experienced the worst bear market and lost about $56 \%$ of its value during this period. They compared the performances of 38 sector index funds using the Sharpe and Treynor portfolio performance measures and found that the healthcare and consumer staples sector index funds had the best performance and the financials and home construction sector index funds had the worst performance in the October 9, 2007-March 9, 2009 bear market run.

Wong and Shum (2010) examined the performances of 15 worldwide ETFs across bearish and bullish markets over the period 1999 to 2007. They observed that ETFs always provide higher returns in a bullish market than in a bearish market. They noted from the Sharpe ratios that ETF returns are not positive and proportional to the market volatility.

Yuexiang et al. (2010) investigated the pricing efficiency of the Shanghai 50 ETF (SSE 50 ETF), the first Exchange-Traded Fund (ETF) in China. They demonstrated that ETF market prices and their Net Asset Values are co-integrated and there is a unidirectional causality from price to NAV. They also found that the fund's prices did not closely follow the NAV during the second half of 2007, when the Chinese stock market experienced substantial volatility, reflecting sudden increased market risks as well as potential arbitrage opportunities during financial turbulences. Gerasimos (2011) found that the performance of ETFs is predictable and the return superiority is persistent in the short term level.

This mixed evidence about performance of ETFs across developed as well as emerging economies warrants and motivated the present research about the performance of ETFs in India.

\subsection{Mutual Fund Performance through Data Envelopment Analysis}

Apart from traditional measures such as the Sharpe ratio and Treynor's ratio, Data Envelopment Analysis (DEA) is found suitable to assess and rank the funds in mutual fund literature. Sedzro and Sardano (2000) observed that DEA provides a good ranking procedure when compared with the Sharpe and Treynor ratios. Anderson et al. (2004) used basic DEA to investigate 257 Australian real estate mutual funds over the 1997-2001 period. Greg (2006) assessed the relative efficiencies and inefficiencies of 25 of the largest US stocks, bonds and balanced funds using DEA. Ioannis (2011) evaluated the performance of natural resources ETFs using DEA and ranked the ETFs based on 3 input and 3 output variables. 


\subsection{Mutual Fund Performance in India}

There are many research papers on the Indian mutual fund (MF) industry. Sivakumar et al. (2010) observed that private players were able to mobilize greater resources in the Indian MF industry than public institutions. Jaspal Singh (2004) evaluated the performance of various mutual funds and found that ICICI prudential floated and managed by a private AMC is the best performer in India. Madhumita et al. (2008) evaluated the performance of mutual funds on the basis of rate of returns as well as risk-adjusted methods, and found that the majority of equity funds outperformed the benchmark index. Most of these studies evaluated the growth and performance of equity funds, but there is no paper on Exchange-Traded Funds in India. Hence, the focus of this paper is to investigate the growth and performance of ETFs in India.

\section{Data and Model}

In India, the first ETF was launched in the year 2001. However, the MF industry in general and the ETFs in particular started growing rapidly only since 2006. Between January 2006 and December 2011, 82 ETF schemes were floated by 22 Asset Management Companies (AMCs). The data for 60 months from April 2006-April 2011 about the categories of AMCs, the monthly net asset values, and the total assets under management of all the 82 schemes were collected from the Association of Mutual Funds in India (AMFI) website.

Through time series data, the growth trend of the total assets under management of ETFs was identified. Monthly returns have been computed from Net Asset Values. Returns were compared across various categories of ETFs to analyze the performance of each category. Further, ETF returns were regressed against the returns of the CNX NIFTY Index (Equity index of 50 stocks maintained by the National Stock Exchange as Proxy for market) to estimate the excess returns (alpha values) that the ETFs provide to investors on and above the market returns. It is expected that ETFs would have high risk-adjusted returns and higher Sharpe ratios. Accordingly, the Sharpe ratio of each individual ETF has been calculated by dividing the excess ETF returns over the risk free rate with the standard deviation of ETF returns.

Further, DEA has been used to appraise and rank all ETFs in a risk- return frame work without reference to the market index. This method is considered appropriate because different ETFs target different benchmarks for their schemes. DEA assesses the relative efficiencies of peer group funds (ETFs) based on linear programming and optimization techniques using multiple input and output variables.

\subsection{Data Envelopment Analysis}

Data Envelopment Analysis is a non-parametric method based on linear programming. DEA analysis ranks the funds based on output-input ratio. Three input and two output variables were selected and used as per the Greg (2006) model. Three input oriented models of DEA - basic, cross and super efficiency models were used to appraise and rank the ETFs. Optimization software MAX DEA has been used to run these models and generate efficiency scores across ETFs.

\subsubsection{Basic Efficiency Model}

Input variables proxy the risk metrics and output variables reflect the return parameters. The Basic Efficiency Model is referred as a constant to the scale model. The objective of this optimization model is to maximize the ratio of output to input variables.

Basic Efficiency:

$$
\begin{aligned}
h_{o}^{*} & =\frac{\max \sum_{r=1}^{s} u_{r} Y_{r o}}{\sum_{i=1}^{m} v_{i} x_{i o}} \\
h_{k j} & =\frac{\sum_{r=1}^{s} Y_{r j} u_{r}}{\sum_{i=1}^{m} x_{i j} v_{i}} \leq 1 j=1,2,3 \ldots . . n
\end{aligned}
$$

$\mathrm{i}=1,2,3 \ldots \mathrm{n} \quad \mathrm{m}$-Input Variables $\quad \mathrm{r}=1,2 \ldots \mathrm{s}$-Output Variables $\mathrm{j}=1,2 \ldots \mathrm{n}$-mutual funds

$\mathrm{V}_{\mathrm{r}}$-Weight of input $\mathrm{i} \quad \mathrm{u}_{\mathrm{r}}$-Weight of output $\mathrm{r}$. 


\subsubsection{Cross Efficiency Model}

This model facilitates peer group evaluation. It computes the efficiency score of each ETF by taking the average of the individual efficiency scores obtained by using optimum weights of all other funds in the group based on the Basic DEA model.

Cross Efficiency:

$$
h_{k j}=\frac{\sum_{r=1}^{s} Y_{r j} u_{r k}}{\sum_{i=1}^{m} x_{i j} v_{i k}} \leq 1 j, k=1,2,3 \ldots \ldots n
$$

$\mathrm{h}_{\mathrm{kj}}$-score of mutual fund $\mathrm{j}$ cross evaluated by mutual fund $\mathrm{k}$

$\mathrm{X}_{\mathrm{ij}}$-Input $\gamma_{\mathrm{rj}}$-Output

$i=1,2 \ldots$-Input variables $\quad r=1,2 \ldots s$-Output variables $j=1,2 \ldots . n$-mutual funds

$V_{i k}$-weight of input $i \quad u_{r k}$-weight of output $r$

4.1.3 Super Efficiency Model

This model is very similar to the basic model except that the objective function is allowed to exceed the value 1 . In other words, the fund for which the efficiency score is being evaluated is not included in the constraint equations of the linear model.

Super Efficiency:

$$
h_{o}^{*}=\frac{\max \sum_{r=1}^{s} u_{r} Y_{r o}}{\sum_{i=1}^{m} v_{i} x_{i o}}
$$

Subject to

$$
\frac{\sum_{r=1}^{s} Y_{r j} u_{r k}}{\sum_{i=1}^{m} x_{i j} v_{i k}} \leq 1 j=1,2,3 \ldots . . n, j \neq 0
$$

$\mathrm{X}_{\mathrm{ij}}$-Input $\mathrm{Y}_{\mathrm{rj}}$-Output $\mathrm{V}_{\mathrm{i}}$-weight of input $\mathrm{i} \quad \mathrm{u}_{\mathrm{r}}$-weight of output $\mathrm{r}$

$\mathrm{i}=1,2 \ldots \mathrm{m}$-Input variables $\mathrm{r}=1,2 \ldots \mathrm{s}-$ Output variables $\mathrm{j}=1,2 \ldots \mathrm{n}$ - mutual funds

\subsection{Input Variables}

Three input variables and two output variables have been used to estimate the relative efficiencies of ETFs in India.

\subsubsection{Standard Deviation}

Standard Deviation is a measure of the volatility of the returns that the mutual fund produces. A high volatility implies high probability of unexpected gain/loss. This is the most accepted and widely used measure of financial risk, and is computed taking deviation from the mean value of all monthly returns.

\subsubsection{Maximum Drawdown}

Maximum Drawdown is a measure of the capability of the fund to rebound from a trough. It is calculated as the largest percentage drop from peak to trough before attaining a new peak during the investigation period. This is considered as an input variable since the period of study covered the world financial crisis phase when the Net Asset Values (NAVs) of almost all the funds fell. This input variable captures the ability of ETFs to rebound and perform better. For example if the NAV fell from its highest value of Rs. 20 to Rs.10 before reaching a new peak of Rs. 21 ,the computed value of drawdown will be $50 \%$.

\subsubsection{Monthly Downside Deviation}

Monthly Downside Deviation is a measure of the volatility of the downside performance of a mutual fund. It is calculated by finding the average negative returns during the investigation period and measuring the deviation of the negative returns around this mean. A small Downside Deviation indicates lesser probability and risk of large negative returns. 


\subsection{Output Variables}

\subsubsection{Profitable month's percentage}

Profitable month's percentage measures the percentage of months with positive returns in the investigation period on the total number of months. This variable captures the persistence of positive performance.

\subsubsection{Compounded Monthly return}

It measures the long term returns generated by the ETF, and is calculated by taking the $\mathrm{n}^{\text {th }}$ root of the total return, where $\mathrm{n}$ is the number of periods being considered. This is computed as follows:

$\left(\left((\text { Net asset value in April 2011)/ (Net asset value in April 2006) })^{\wedge} 1 / 60\right)-1\right.$

This variable does not capture the interval monthly returns during the entire period. This indicates that the return an investor would get if he holds the fund for long term (5 years from April 2006-2011).

\section{Empirical Results}

\subsection{ETFs-Origin and Growth in India}

The growth in Indian ETFs was predominant during 2006-07 (Figure 3). The global financial crisis halted the trend during 2008-2009.

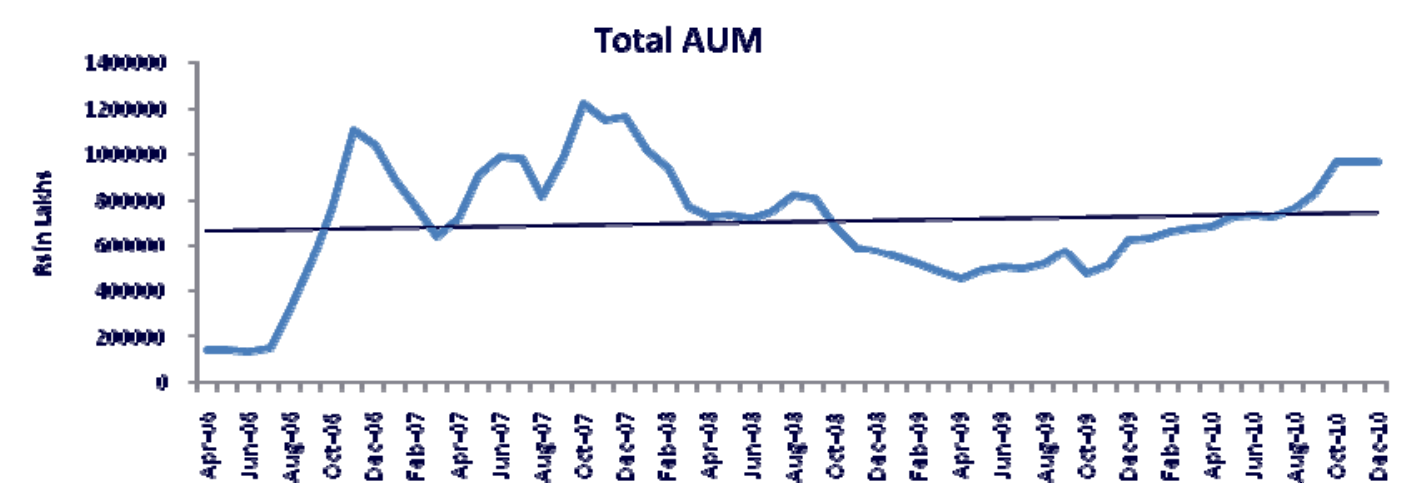

Figure 3. Total assets under management across all ETFS

Figure 4 to Figure 7 presents the growth pattern in fund size, and Figure 8 presents the comparative pattern. Gold Funds first started in 2007 and have grown continuously over the 5 year period. During the financial crisis investors found gold to be an alternative performing asset class. The investment level was sustained in fund of fund overseas during the crisis period. The total investments did not fall. The fund of funds domestic as well as other funds based on Indian indices fell substantially during the crisis period. The other ETFs which are mostly index funds are yet to begin attracting additional funds after the halt.

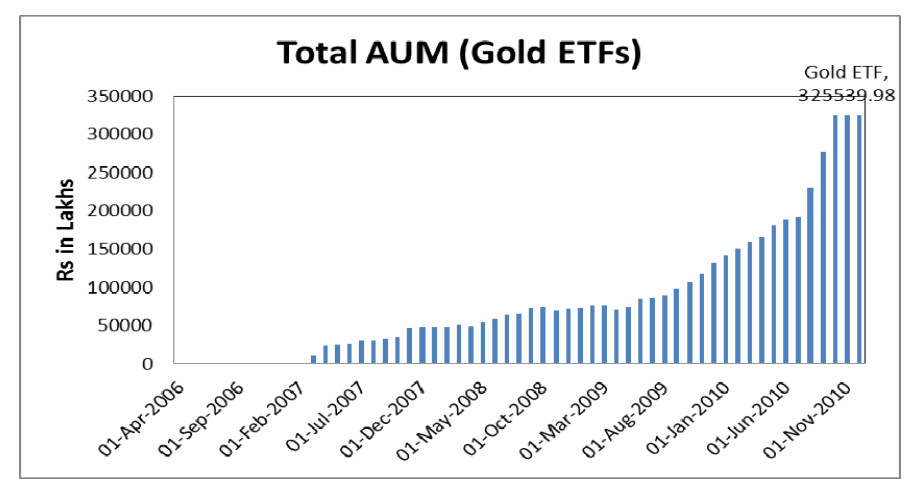

Figure 4. Monthwise AUM distribution-Gold ETFs 


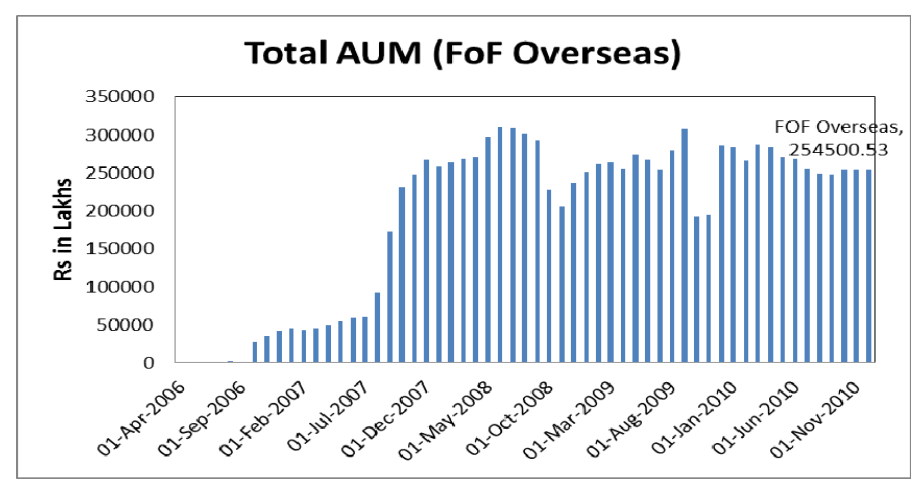

Figure 5. Monthwise AUM distribution-FoF overseas figure

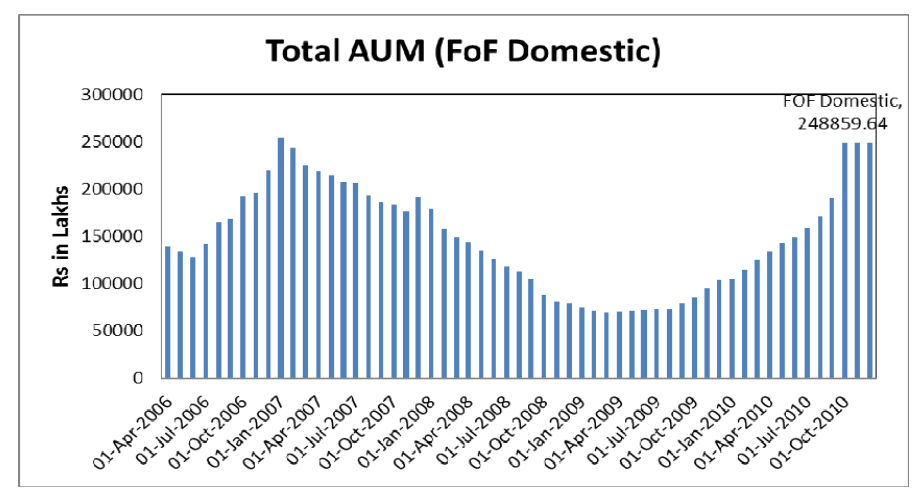

Figure 6. Monthwise AUM distribution-FoF domestic

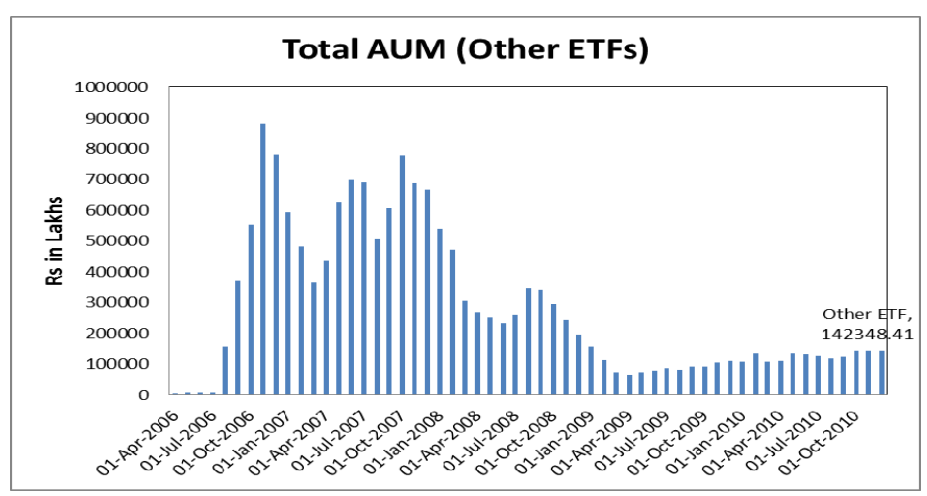

Figure 7. Monthwise AUM distribution-Other ETFs 


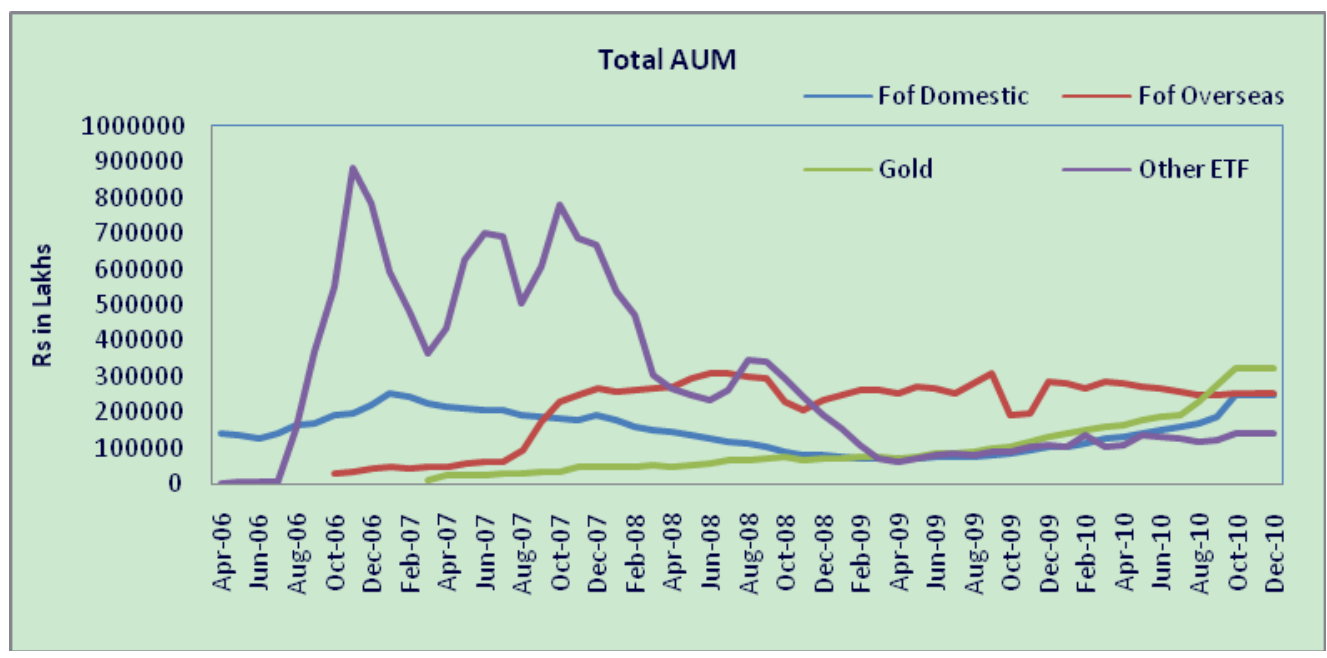

Figure 8. Comparative Analysis of ETFs based on monthly AUMs

Table 1 presents the compounded growth rates for all the categories of ETFs in India for the period 2006-2010. On an average, ETFs grew at $37 \%$ compounded annually as against reported global growth rate of $26 \%$ during this period (Black Rock report).

As already observed, the growth rate across all ETFs was very high during 2006-07. The total investments in the subsequent years fell due to the crash of the financial markets across the globe. On the whole, the domestic fund of funds had a negative compounded growth rate over the five year study period, whereas, overseas fund of funds grew @ 80\%, and Gold ETFs grew by 94\%. As for the other ETFs, though they fell drastically during the crisis time, they still generated the highest average compounded growth rate over the 5 year period.

Table 1. Growth rates and returns across the different types of 82 ETFs in India

\begin{tabular}{|c|c|c|c|c|c|}
\hline S.No & Type & Year & $\begin{array}{c}\text { Total AUM (RS.in } \\
\text { Lakhs) }\end{array}$ & $\begin{array}{c}\text { Year on Year Growth } \\
\text { rate } \\
\end{array}$ & $\begin{array}{c}\text { CAGR } \\
(2006-2011) \\
\end{array}$ \\
\hline \multirow[t]{5}{*}{1.} & FOF-Domestic & 1-Apr-07 & 139486.62 & $\mathrm{~N} / \mathrm{A}$ & \\
\hline & & 1-Apr-08 & 218812.94 & $56.87 \%$ & \\
\hline & & 1-Apr-09 & 144460.46 & $-33.98 \%$ & $-.90 \%$ \\
\hline & & 1-Apr-10 & 70629.80 & $-51.11 \%$ & \\
\hline & & 1-Apr-11 & 133341.34 & $88.79 \%$ & \\
\hline \multirow[t]{5}{*}{2.} & FOF-Overseas & 1-Apr-07 & N/A & N/A & \\
\hline & & 1-Apr-08 & 48738.62 & N/A & \\
\hline & & 1-Apr-09 & 270076.13 & $454.00 \%$ & $52.20 \%$ \\
\hline & & 1-Apr-10 & 255134.67 & $-6.00 \%$ & \\
\hline & & 1-Apr-11 & 282772.39 & $11.00 \%$ & \\
\hline \multirow[t]{5}{*}{3.} & Gold ETF & 1-Apr-07 & N/A & N/A & \\
\hline & & 1-Apr-08 & 22640.42 & N/A & \\
\hline & & 1-Apr-09 & 47978.21 & $112.00 \%$ & $64.20 \%$ \\
\hline & & 1-Apr-10 & 70187.81 & $46.00 \%$ & \\
\hline & & 1-Apr-11 & 165089.10 & $135.00 \%$ & \\
\hline \multirow[t]{3}{*}{4.} & Other ETF & 1-Apr-07 & 2489.93 & N/A & \\
\hline & & 1-Apr-08 & 433983.93 & $17330.00 \%$ & $113.00 \%$ \\
\hline & & 1-Apr-09 & 267741.10 & $-38.00 \%$ & \\
\hline
\end{tabular}




\begin{tabular}{|c|c|c|c|c|c|}
\hline & & 1-Apr-10 & 62391.50 & $-77.00 \%$ & \\
\hline & & 1-Apr-11 & 108510.53 & $74.00 \%$ & \\
\hline \multirow[t]{5}{*}{5.} & Total ETF & 1-Apr-07 & 141976.55 & N/A & \\
\hline & & 1-Apr-08 & 724175.91 & $410.07 \%$ & \\
\hline & & 1-Apr-09 & 730255.90 & $0.84 \%$ & $37.00 \%$ \\
\hline & & 1-Apr-10 & 458343.78 & $-37.24 \%$ & \\
\hline & & 1-Apr-11 & 689713.36 & $50.48 \%$ & \\
\hline
\end{tabular}

Table 2 presents various categories of asset management companies (AMCs) and their asset composition. Across the various players, foreign AMCs floated the maximum number of ETFs and are holding the highest value of investments. Foreign AMCs own 55\% of the total ETF assets, Indian Joint Ventures own 24\% and private Indian AMCs own $15 \%$ of the assets.

Table 2. Asset under management by various categories of asset management companies as on $31^{\text {st }}$ December, 2011

\begin{tabular}{|c|c|c|c|c|c|}
\hline S.No & Category & No. of AMCs & No of ETFs & $\begin{array}{c}\text { Total AUMs } \\
\text { (Rupees in lakhs) }\end{array}$ & $\begin{array}{c}\% \text { Share in } \\
\text { total } \\
\text { investments }\end{array}$ \\
\hline 1 & $\begin{array}{c}\text { Bank Joint Venture-Predominantly } \\
\text { Indian }\end{array}$ & 1 & 1 & 15548.25 & $1.74 \%$ \\
\hline 2 & Bank Sponsored & 1 & 1 & 75.35 & $0.01 \%$ \\
\hline 3 & Private Foreign & 5 & 26 & 496706.4 & $55.48 \%$ \\
\hline 4 & Private Indian & 8 & 17 & 130256.1 & $14.55 \%$ \\
\hline 5 & $\begin{array}{c}\text { Private Joint } \\
\text { Venture-Predominantly Foreign }\end{array}$ & 3 & 14 & 37135.52 & $4.15 \%$ \\
\hline 6 & $\begin{array}{c}\text { Private Joint } \\
\text { Venture-Predominantly Indian }\end{array}$ & 4 & 23 & 215519.3 & $24.07 \%$ \\
\hline & Total & 22 & 82 & 895240.92 & $100.00 \%$ \\
\hline
\end{tabular}

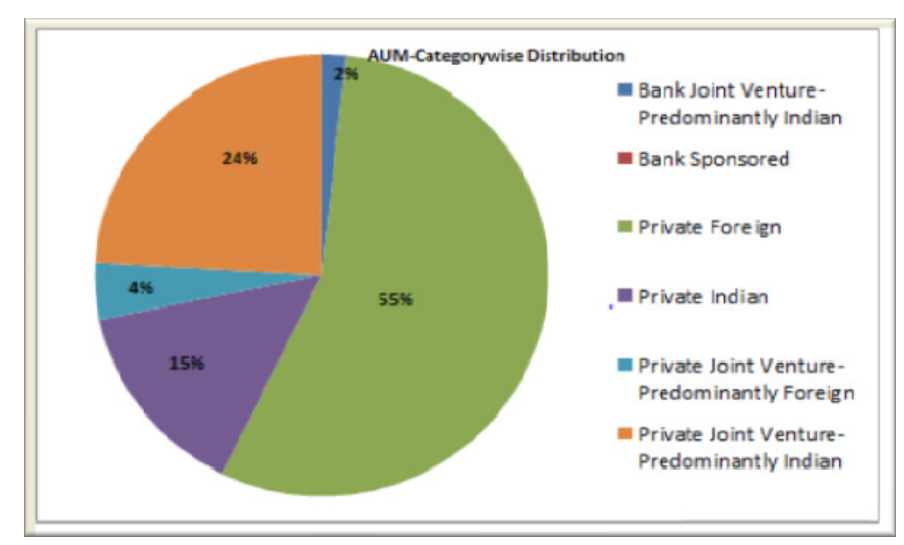

Figure 9. Category-wise distribution based on AUM 


\subsection{ETFs Performance}

\subsubsection{Comparative Analysis of Returns}

Table 3 presents the average monthly returns across the schemes and across the years. ETFs floated upon Indian stock market indices and categorized as other ETFs, provided higher returns both in the period of boom as well as during the recovery phase. This was despite the fact that the total AUM dipped drastically since 2008 in these funds. Overseas Fund of funds also gave equally higher returns to the investors across the years. All ETFs had negative returns during the year 2008-09 on account of the global financial crisis.

Table 3. Average monthly returns of 82 ETFs in India

\begin{tabular}{ccccccc}
\hline Year & FOF-domestic & FOF-overseas & Gold ETF & Other ETF & Average Return & Nifty Return \\
\hline Apr 06 - Mar 07 & $0.46 \%$ & $0.93 \%$ & & $0.96 \%$ & $0.78 \%$ & $0.44 \%$ \\
Apr 07 - Mar 08 & $1.04 \%$ & $1.32 \%$ & $2.15 \%$ & $1.67 \%$ & $1.55 \%$ & $1.38 \%$ \\
Apr 08 - Mar 09 & $-1.10 \%$ & $-2.90 \%$ & $-1.69 \%$ & $-2.53 \%$ & $-2.06 \%$ & $-4.52 \%$ \\
Apr 09- Mar 10 & $2.60 \%$ & $3.04 \%$ & $-0.78 \%$ & $5.79 \%$ & $2.66 \%$ & $4.17 \%$ \\
Apr 10 - Mar 11 & $0.68 \%$ & $1.56 \%$ & $0.12 \%$ & $1.25 \%$ & $0.90 \%$ & $0.30 \%$ \\
\hline
\end{tabular}

Table 4 provides the comparative descriptive statistics. All categories of ETFs outperformed the market benchmark. The average monthly return on ETFs during the five year study period of 2006-11 is more than twice the return upon equity market index. The standard deviation which measures volatility is less than half of the market index. This infers that ETF investors take less than half of the market risk to earn a return that is twice that of market return.

Table 4. Descriptive statistics of monthly returns of 82 ETFS during April 2006-April 2011

\begin{tabular}{ccccccc}
\hline & $\begin{array}{c}\text { FoF } \\
\text { Domestic }\end{array}$ & $\begin{array}{c}\text { FoF } \\
\text { Overseas }\end{array}$ & $\begin{array}{c}\text { Gold } \\
\text { ETF }\end{array}$ & $\begin{array}{c}\text { Other } \\
\text { ETFs }\end{array}$ & $\begin{array}{c}\text { Average } \\
\text { Return }\end{array}$ & $\begin{array}{c}\text { Nifty } \\
\text { Return }\end{array}$ \\
\hline Maximum & $11.75 \%$ & $12.04 \%$ & $11.75 \%$ & $31.02 \%$ & $11.66 \%$ & $21.92 \%$ \\
Minimum & $-9.50 \%$ & $-22.84 \%$ & $-14.85 \%$ & $-22.35 \%$ & $-16.87 \%$ & $-35.89 \%$ \\
Average & $0.72 \%$ & $0.78 \%$ & $1.69 \%$ & $0.91 \%$ & $0.79 \%$ & $0.36 \%$ \\
$\begin{array}{c}\text { Standard } \\
\text { deviation }\end{array}$ & $3.59 \%$ & $5.55 \%$ & $5.27 \%$ & $8.60 \%$ & $3.88 \%$ & $9.04 \%$ \\
\hline
\end{tabular}

\subsubsection{ETF's Performance: Excess Returns}

Single index model based on the classical Capital Asset Pricing has been used to compute alpha and beta. Using CNX NIFTY as the market index, Jensen's alpha was computed for various categories of ETF via the regression of the excess return of the index against the excess return of the ETF as follows:

$$
\mathrm{R}_{\mathrm{et}}-\mathrm{R}_{\mathrm{f}}=\alpha+\beta\left(\mathrm{R}_{\mathrm{it}}-\mathrm{R}_{\mathrm{f}}\right)+\varepsilon_{\mathrm{t}}
$$

where $R_{e t}$ and $R_{i t}$ are the monthly return for the ETF and equity market index NIFTY at time $t, R_{f}$ is the risk-free rate proxy and $\varepsilon_{t}$ is an error term. $\alpha$ represents Jensen's alpha (1968), which is the intercept of the regression in the excess risk-adjusted return above that of the market index and $\beta$ is the slope of the regression.

The regression results and beta estimates provide insights into the level of the ETFs' dependency upon the market performance. The alpha values reflect the excess returns the funds were able to provide on and above the market benchmark. Except in the case of gold ETFs where the underlying asset is gold and not equity market index, in all 
the other cases the beta coefficients are statistically significant, leading to the inference that their performance depends upon market performance. ETFs floated on Indian indices (categorized as other ETFs) had the highest betas whereas domestic and overseas fund of funds had moderate but statistically significant betas. R square of $79 \%$ between the average ETFs returns and the market returns further indicates their performance dependence on the market performance. The alpha values were positive though not statistically significant, indicating positive excess returns even during the crisis times. These values indicate excess monthly returns generated by ETFs; they have been compounded over a period of 12 months and the computed annualized average excess return is presented in Table 5. Gold ETFs provided highest excess returns of 13\% p.a. On an average, ETFs provided 3\% excess return over the market benchmark during the 5 year period of 2006-2011. Excess annual return of $12 \%$ on ETFs floated on Indian indices and referred as other ETFs was found to be statistically significant.

Table 5. Regression estimates

\begin{tabular}{ccccccc}
\hline S. No. & Fund & $\begin{array}{c}\text { Jenson } \\
\text { Alpha }\end{array}$ & Beta Coefficient & R Square & $\begin{array}{c}\text { Compounded } \\
\text { annualexcess } \\
\text { returns }\end{array}$ & $\begin{array}{c}\text { Sharpe } \\
\text { Ratio }\end{array}$ \\
\hline 1 & Gold & 0.0103 & 0.0159 & 0.0008 & $13.08 \%$ & 0.6754 \\
2 & Other ETFs & $0.0098^{* *}$ & $0.8635^{* * *}$ & 0.8674 & $12.41 \%$ & 0.3655 \\
3 & Fund of Funds: Overseas & 0.0027 & $0.4911^{* * *}$ & 0.6409 & $3.28 \%$ & 0.0729 \\
4 & Fund of Funds: Domestic & 0.0018 & $0.3796^{* * *}$ & 0.9142 & $2.18 \%$ & 0.0596 \\
5 & Average & 0.0025 & $0.3838^{* * *}$ & 0.7983 & $3.04 \%$ & 0.1177 \\
\hline
\end{tabular}

$* 90 \%$ significance level, $* * 95 \%$ significance level, $* * * 99 \%$ significance level

\subsubsection{Performance Ranking across ETFs using the Data Envelopment Analysis (DEA) Model}

Data Envelopment Analysis ranks the funds having higher output to input ratio as efficient funds. Input variables describe the risk characters while output variables represent return characters. Standard Deviation, maximum Drawdown and monthly Downside Deviation were the input variables, and profitable month's percentage and compounded monthly returns were included as output variables. The basic efficiency scores have been computed for all 35 ETFs that were launched by various categories of AMCs in India by the end of December 2006. Three input variables and three output variables were included for generating basic efficiency scores. For all these ETFs super efficiency and cross efficiency scores have been estimated and reported in Table 6. Further, Sharpe ratios have also been computed (Table 6), for which, the yield on 10 years' Government bonds have been considered as risk free rate. The Sharpe ratio was computed from the following formula.

Sharpe ratios were small for some funds as they had low average monthly returns for many months due to negative returns during the years 2008 and 2009. 
Table 6. Efficiency scores of all 35 ETFs floated till December 2006 based on their performance between Jan 2007-May 2011

\begin{tabular}{|c|c|c|c|c|c|c|}
\hline Fund Name & $\begin{array}{l}\text { Annualize } \\
\text { d Return }\end{array}$ & $\begin{array}{l}\text { Sharp } \\
\text { e Ratio }\end{array}$ & $\begin{array}{c}\text { Basic } \\
\text { efficien } \\
\text { cy }\end{array}$ & $\begin{array}{c}\text { Super } \\
\text { efficien } \\
\text { cy }\end{array}$ & $\begin{array}{c}\text { Mean } \\
\text { Cross } \\
\text { Efficie } \\
\text { ncy }\end{array}$ & $\begin{array}{c}\text { AMC } \\
\text { Category }\end{array}$ \\
\hline $\begin{array}{l}\text { FT India Life Stage Fund of Funds - The 50s } \\
\text { Plus Flo (G) }\end{array}$ & 10.4775 & 0.4707 & 1.0000 & 1.2999 & 1.0062 & Pvt.(F) \\
\hline $\begin{array}{l}\text { Birla Sun Life Asset Allocation } \\
\text { Fund-Conservative Plan-(D) }\end{array}$ & 9.1481 & 0.1991 & 1.0000 & 1.0000 & 0.8985 & Pvt. JV(I) \\
\hline $\begin{array}{l}\text { Birla Sun Life Asset Allocation } \\
\text { Fund-Conservative Plan- }(\mathrm{G})\end{array}$ & 9.1481 & 0.1991 & 1.0000 & 1.0000 & 0.8985 & Pvt. JV(I) \\
\hline Principal Global Opportunities Fund-(D) & 9.0972 & 0.0486 & 1.0000 & 1.0000 & 0.3110 & Pvt. JV(F) \\
\hline Principal Global Opportunities Fund-(G) & 9.0972 & 0.0486 & 1.0000 & 1.0000 & 0.3110 & Pvt. JV(F) \\
\hline $\begin{array}{l}\text { FT India Life Stage Fund Of Funds-The } 50+\mathrm{S} \\
\text { Plan }(\mathrm{G})\end{array}$ & 11.5144 & 0.4308 & 0.7667 & 0.7667 & 0.6922 & \\
\hline ICICI Prudential Cautious Plan & 11.4135 & 0.4303 & 0.7458 & 0.7458 & 0.6578 & \\
\hline $\begin{array}{l}\text { ICICI Prudential Cautious Plan-Dividend } \\
\text { Option }\end{array}$ & 11.4135 & 0.4303 & 0.7458 & 0.7458 & 0.6578 & \\
\hline $\begin{array}{l}\text { FT India Life Stage Fund Of Funds-The 40s } \\
\qquad \text { Plan }(\mathrm{G})\end{array}$ & 14.4639 & 0.5555 & 0.7126 & 0.7126 & 0.6106 & \\
\hline $\begin{array}{l}\text { Nifty Benchmark Exchange Traded } \\
\text { Scheme-Nifty BeES }\end{array}$ & 12.9217 & 0.1611 & 0.7073 & 0.7073 & 0.2671 & \\
\hline ICICI Prudential Very Aggressive Plan & 10.8613 & 0.1166 & 0.7024 & 0.7024 & 0.2674 & \\
\hline $\begin{array}{l}\text { ICICI Prudential Very Aggressive } \\
\text { Plan-Dividend Option }\end{array}$ & 10.8613 & 0.1166 & 0.7024 & 0.7024 & 0.2674 & \\
\hline $\begin{array}{c}\text { FT India Dynamic PE Ratio Fund of } \\
\text { Funds-Growth }\end{array}$ & 5.0000 & 0.6830 & 0.6565 & 0.6565 & 0.5610 & \\
\hline $\begin{array}{l}\text { FT India Life Stage Fund Of Funds-The 30s } \\
\text { Plan (G) }\end{array}$ & 15.5873 & 0.5256 & 0.5932 & 0.5932 & 0.5086 & \\
\hline $\begin{array}{l}\text { FT INDIA Life Stage Fund Of Funds-The 30S } \\
\text { Plan (D) }\end{array}$ & 15.5873 & 0.5256 & 0.5932 & 0.5932 & 0.4905 & \\
\hline $\begin{array}{l}\text { FT India Life Stage Fund Of Funds-The 40s } \\
\text { Plan (D) }\end{array}$ & 11.6658 & 0.3078 & 0.5427 & 0.5427 & 0.4347 & \\
\hline $\begin{array}{l}\text { FT India Life Stage Fund Of Funds-The } 20 \mathrm{~s} \\
\text { Plan (D) }\end{array}$ & 20.2414 & 0.5880 & 0.5244 & 0.5244 & 0.4296 & \\
\hline $\begin{array}{l}\text { FT India Life Stage Fund Of Funds-The } 20 \text { s } \\
\qquad \text { Plan }(\mathrm{G})\end{array}$ & 20.2414 & 0.5880 & 0.5244 & 0.5244 & 0.4437 & \\
\hline $\begin{array}{l}\text { FT India Dynamic PE Ratio Fund of } \\
\text { Funds-Dividend }\end{array}$ & 13.7957 & 0.3356 & 0.4627 & 0.4627 & 0.3878 & \\
\hline $\begin{array}{l}\text { ING OptiMix Asset Allocator Multi-Manager } \\
\qquad \text { FoF Scheme - (G) }\end{array}$ & 10.3555 & 0.1220 & 0.4453 & 0.4453 & 0.3316 & \\
\hline $\begin{array}{c}\text { Birla Sun Life Asset Allocation } \\
\text { Fund-Moderate Plan-(D) }\end{array}$ & 11.4790 & 0.2215 & 0.4251 & 0.4251 & 0.3647 & \\
\hline $\begin{array}{l}\text { Birla Sun Life Asset Allocation } \\
\text { Fund-Moderate Plan-(G) }\end{array}$ & 11.4790 & 0.2215 & 0.4251 & 0.4251 & 0.3647 & \\
\hline $\begin{array}{l}\text { ING OptiMix Asset Allocator Multi-Manager } \\
\qquad \text { FoF Scheme -( D) }\end{array}$ & 8.2772 & 0.0174 & 0.4081 & 0.4081 & 0.2527 & \\
\hline
\end{tabular}




\begin{tabular}{|c|c|c|c|c|c|}
\hline $\begin{array}{l}\text { Banking Index Benchmark Exchange Traded } \\
\text { Scheme (Bank BeES) }\end{array}$ & 24.0328 & 0.3896 & 0.3453 & 0.3453 & 0.2894 \\
\hline $\begin{array}{l}\text { Birla Sun Life Asset Allocation } \\
\text { Fund-Aggressive Plan-(D) }\end{array}$ & 12.8270 & 0.2255 & 0.3444 & 0.3444 & 0.3049 \\
\hline $\begin{array}{l}\text { Birla Sun Life Asset Allocation } \\
\text { Fund-Aggressive Plan-(G) }\end{array}$ & 12.8270 & 0.2255 & 0.3444 & 0.3444 & 0.3049 \\
\hline ICICI Prudential Moderate Plan & 9.6502 & 0.1178 & 0.3408 & 0.3408 & 0.2865 \\
\hline $\begin{array}{l}\text { ICICI Prudential Moderate Plan-Dividend } \\
\text { Option }\end{array}$ & 9.6502 & 0.1178 & 0.3408 & 0.3408 & 0.2865 \\
\hline ICICI Prudential Aggressive Plan & 10.8958 & 0.1490 & 0.2829 & 0.2829 & 0.2327 \\
\hline $\begin{array}{l}\text { ICICI Prudential Aggressive Plan-Dividend } \\
\text { Option }\end{array}$ & 10.8958 & 0.1490 & 0.2829 & 0.2829 & 0.2327 \\
\hline $\begin{array}{l}\text { Nifty Junior Benchmark Exchange Traded } \\
\text { Scheme (Junior BeES) }\end{array}$ & 19.4976 & 0.2945 & 0.2572 & 0.2572 & 0.2217 \\
\hline UTI Sunder & 14.3286 & 0.2098 & 0.2433 & 0.2433 & 0.2109 \\
\hline Kotak Equity-FOF-Growth & 12.7146 & 0.1641 & 0.2257 & 0.2257 & 0.1958 \\
\hline Kotak Equity-FOF-Dividend & 12.0294 & 0.1407 & 0.2136 & 0.2136 & 0.1849 \\
\hline $\begin{array}{l}\text { Sensex ICICI Prudential Exchange Traded } \\
\text { Fund }\end{array}$ & 12.2570 & 0.1454 & 0.2132 & 0.2132 & 0.1888 \\
\hline
\end{tabular}

The scheme names are abbreviated as follows: D indicates Dividend payout option; G indicates Growth Plans; FoF indicates Fund of funds.

Fund Type is abbreviated as follows: Pvt.(F) indicates foreign private Asset Management Companies(AMC); Pvt.(I) indicates private Indian AMC; Pvt. JV(I) indicates Private Joint Ventures-Predominantly Indian; Pvt. JV(F) indicates Private Joint Ventures-Predominantly Foreign.

The basic efficiency score of 1 indicates that the fund is efficient. Higher cross efficiency across basic efficient funds indicates their superior performance across peer funds. Super efficiency further ranks efficient funds. It is observed that the model ranked 5 funds to be efficient across 35 funds over the period of 52 months from $1^{\text {st }}$ Jan 2007 to April 2011.Out of these funds the first 3 funds were domestic fund of funds and the other two were overseas fund of funds. These five funds were floated by 3 AMCs. A popular foreign AMC, Franklin Templeton floated the first best fund. This fund has been found to be efficient by all the three basic, super and cross efficiency models. Birla Sun life a Joint Venture, where the Indian partner has a predominant share floated the next two best funds. These funds were found to be superior by basic and super efficiency models but did not get an efficiency score equal or higher than one in the cross efficiency model. The last two funds were floated by Principal Global opportunities which was also a Joint Venture but with the predominant share held by a foreign partner. The best funds were neither the funds with higher Sharpe ratios nor the funds with highest returns. This infers that funds providing higher returns are not considered as efficient funds. The average annualized return across the funds was $11 \%$ and the ETFs that were found efficient had a return of 9-10\%. Though Sharpe ratios are widely used to rank the fund's performance, the inclusion of other parameters in this optimization model to provide for consistent performance ranked the funds differently. The Maximum Drawdown and monthly Downside Deviation are the two additional input variables that were key variables, particularly during the crisis time to filter efficient funds from peer group. ETFs were also found to have lower Sharpe ratios as they had negative returns in two out of these 4 years time. The correlation between the basic efficiency scores the Sharpe ratios was very low as is presented in Table 9.

In India, 67 ETFs were floated up to end of the December 2008. With the twin objectives of increasing sample size and also to avoid the crisis years to find efficient funds in normal market conditions, DEA optimization model was employed to rank all these 67 funds on the same 3 input and 2 output variables. The performance of these funds has been analyzed for a period of 29 months - from $1^{\text {st }}$ Jan 2009 to $31^{\text {st }}$ May 2011.

Table 7 presents the efficiency scores of all 67 ETFs. The funds which were found efficient in the previous 
analysis were found to be efficient here also. Out of the 67 ETFs, 9 funds were found to be efficient having a basic efficiency score of above one. Four funds floated by Franklin Templeton were found efficient by the basic model. All were domestic fund of funds. One more domestic fund floated by ING optimix, a foreign AMC and two domestic funds floated by Birla Sun life an AMC that is an Indian Joint Venture were also found to be efficient.. Another foreign AMC, HSBC, has floated two efficient overseas funds of funds. The correlation between the efficiency scores and Sharpe ratios improved (Table 9). The efficient funds were found to have higher Sharpe ratios. Further, the Pearson's correlation coefficient between the Sharpe ratios and estimated efficiency scores was found statistically significant at .01 level, indicating that the DEA ranking is broadly in consensus with the evaluation by Sharpe ratios.

Table 7. Efficiency scores of all 67 ETFs floated till December 2008 based on their performance for period Jan 2009-May 2011

\begin{tabular}{|c|c|c|c|c|c|c|}
\hline Fund Name & $\begin{array}{l}\text { Annualiz } \\
\text { ed } \\
\text { Returns }\end{array}$ & $\begin{array}{c}\text { Sharp e } \\
\text { Ratio }\end{array}$ & $\begin{array}{c}\text { Basic } \\
\text { Efficiency }\end{array}$ & $\begin{array}{c}\text { Super } \\
\text { Efficiency }\end{array}$ & $\begin{array}{c}\text { Mean } \\
\text { Cross } \\
\text { Efficiency }\end{array}$ & $\begin{array}{c}\text { AMC } \\
\text { Category }\end{array}$ \\
\hline $\begin{array}{l}\text { FT India Life Stage Fund of Funds-The } \\
\text { 50s Plus Flo }(\mathrm{G})\end{array}$ & 20.59 & 0.8674 & 1.0000 & 1.3232 & 0.9931 & Pvt.(F) \\
\hline $\begin{array}{l}\text { Ft India Life Stage Fund Of Funds-The } \\
\text { 40s Plan }(\mathrm{G})\end{array}$ & 23.30 & 1.2174 & 1.0000 & 1.0706 & 0.8413 & Pvt.(F) \\
\hline $\begin{array}{c}\text { Ft India Life Stage Fund Of Funds - } \\
\text { The 30s Plan (G) }\end{array}$ & 26.60 & 1.2445 & 1.0000 & 1.0079 & 0.8195 & Pvt.(F) \\
\hline $\begin{array}{l}\text { ING Optimix Income Growth Multi- } \\
\text { FoF-30\% Equity Plan Option A (D) }\end{array}$ & 36.46 & 0.9349 & 1.0000 & 1.0003 & 0.7392 & Pvt.JV(F) \\
\hline $\begin{array}{l}\text { Birla Sun Life Asset Allocation } \\
\text { Fund-Conservative Plan(D) }\end{array}$ & 12.76 & 0.8125 & 1.0000 & 1.0000 & 0.8612 & Pvt.JV(I) \\
\hline HSBC Emerging Markets Fund (D) & 29.85 & 2.6172 & 1.0000 & 1.0000 & 0.7899 & Pvt.(F) \\
\hline HSBC Emerging Markets Fund (G) & 29.85 & 2.6172 & 1.0000 & 1.0000 & 0.7899 & Pvt.(F) \\
\hline $\begin{array}{c}\text { Ft India Life Stage Fund Of Funds - } \\
\text { The 30s Plan (D) }\end{array}$ & 18.95 & 1.1608 & 1.0000 & 1.0000 & 0.3398 & Pvt.JV(I) \\
\hline $\begin{array}{l}\text { Birla Sun Life Asset Allocation } \\
\text { Fund-Conservative Plan }(G) \\
\text { ING Optimix Income Growth }\end{array}$ & 12.76 & 0.8125 & 1.0000 & 1.0000 & 0.3398 & \\
\hline $\begin{array}{c}\text { Multi-Manager FoF } 30 \% \text { Equity Plan } \\
\text { Option A -(G) }\end{array}$ & 38.02 & 0.9835 & 0.9998 & 0.9998 & 0.7391 & \\
\hline $\begin{array}{c}\text { Ft India Life Stage Fund Of Funds - } \\
\text { The 20s Plan }(G)\end{array}$ & 36.76 & 1.2662 & 0.9467 & 0.9467 & 0.3048 & \\
\hline $\begin{array}{c}\text { Ft India Life Stage Fund Of Funds - } \\
\text { The 20s Plan (D) }\end{array}$ & 27.57 & 1.2537 & 0.9467 & 0.9467 & 0.1641 & \\
\hline ICICI Prudential Moderate Plan & 33.73 & 1.1048 & 0.9418 & 0.9418 & 0.7587 & \\
\hline ICICI Prudential Moderate Plan (D) & 33.73 & 1.1048 & 0.9418 & 0.9418 & 0.7587 & \\
\hline $\begin{array}{c}\text { Ft India Life Stage Fund Of Funds - } \\
\text { The 50+S Plan (G) }\end{array}$ & 12.81 & 0.9287 & 0.8704 & 0.8704 & 0.7469 & \\
\hline $\begin{array}{c}\text { FT India Dynamic PE Ratio Fund of } \\
\text { Funds(G) }\end{array}$ & 28.83 & 1.1625 & 0.8695 & 0.8695 & 0.6680 & \\
\hline ICICI Prudential Aggressive Plan & 15.59 & 1.2554 & 0.8587 & 0.8587 & 0.6886 & \\
\hline ICICI Prudential Aggressive Plan (D) & 15.59 & 1.2554 & 0.8587 & 0.8587 & 0.6886 & \\
\hline $\begin{array}{l}\text { Birla Sun Life Asset Allocation } \\
\text { Fund-Aggressive Plan(D) }\end{array}$ & 34.64 & 1.1366 & 0.8494 & 0.8494 & 0.6742 & \\
\hline $\begin{array}{l}\text { Birla Sun Life Asset Allocation } \\
\text { Fund-Aggressive Plan- }(\mathrm{G})\end{array}$ & 34.64 & 1.1366 & 0.8494 & 0.8494 & 0.6742 & \\
\hline $\begin{array}{c}\text { ING OptiMix } 5 \text { Star Multi-Manager } \\
\text { FoF Scheme (D) }\end{array}$ & 19.00 & 1.2767 & 0.8341 & 0.8341 & 0.6509 & \\
\hline
\end{tabular}




\begin{tabular}{|c|c|c|c|c|c|}
\hline $\begin{array}{c}\text { ING OptiMix } 5 \text { Star Multi-Manager } \\
\text { FoF Scheme }(G)\end{array}$ & 19.00 & 1.2754 & 0.8338 & 0.8338 & 0.6506 \\
\hline $\begin{array}{l}\text { Birla Sun Life Asset Allocation } \\
\text { Fund-Moderate Plan(D) }\end{array}$ & 25.00 & 1.0452 & 0.8322 & 0.8322 & 0.3386 \\
\hline $\begin{array}{l}\text { Birla Sun Life Asset Allocation } \\
\text { Fund-Moderate Plan }(\mathrm{G})\end{array}$ & 25.00 & 1.0452 & 0.8322 & 0.8322 & 0.6831 \\
\hline $\begin{array}{l}\text { Nifty Junior Benchmark Exchange } \\
\text { Traded Scheme (Junior BeES) }\end{array}$ & 35.44 & 1.3108 & 0.8301 & 0.8301 & 0.6267 \\
\hline $\begin{array}{l}\text { FT India Life Stage Fund of Funds The } \\
\text { 50s Plus Flo (D) }\end{array}$ & 33.60 & 1.1494 & 0.8193 & 0.8193 & 0.5268 \\
\hline ICICI Prudential Cautious Plan & 22.39 & 1.1133 & 0.7971 & 0.7971 & 0.7370 \\
\hline ICICI Prudential Cautious Plan (D) & 22.39 & 1.1133 & 0.7971 & 0.7971 & 0.7370 \\
\hline Kotak Equity-FOF (G) & 39.01 & 0.9254 & 0.7427 & 0.7427 & 0.5609 \\
\hline ICICI Prudential Very Aggressive Plan & 28.76 & 0.8144 & 0.7179 & 0.7179 & 0.5857 \\
\hline $\begin{array}{l}\text { ICICI Prudential Very Aggressive Plan } \\
\text { (D) }\end{array}$ & 30.26 & 0.8257 & 0.7179 & 0.7179 & 0.5857 \\
\hline Kotak Equity-FOF (D) & 53.73 & 0.9266 & 0.7095 & 0.7095 & 0.5305 \\
\hline Sundaram Global Advantage Fund (G) & 37.95 & 1.3390 & 0.7019 & 0.7019 & 0.5477 \\
\hline Sundaram Global Advantage Fund (D) & 37.95 & 0.9436 & 0.7019 & 0.7019 & 0.5477 \\
\hline ING Latin America Equity Fund(G) & 39.19 & 1.1979 & 0.6766 & 0.6766 & 0.5288 \\
\hline ING Latin America Equity Fund (D) & 39.18 & 1.1991 & 0.6762 & 0.6762 & 0.5288 \\
\hline $\begin{array}{l}\text { ING OptiMix Global Commodities } \\
\text { Fund }(\mathrm{G})\end{array}$ & 11.22 & 0.5067 & 0.6756 & 0.6756 & 0.4734 \\
\hline $\begin{array}{c}\text { ING OptiMix Global Commodities } \\
\text { Fund(D) }\end{array}$ & 11.22 & 0.5067 & 0.6745 & 0.6745 & 0.4719 \\
\hline $\begin{array}{l}\text { Ft India Life Stage Fund Of Funds - } \\
\text { The 40s Plan (D) }\end{array}$ & 11.29 & 0.2254 & 0.6733 & 0.6733 & 0.4561 \\
\hline $\begin{array}{c}\text { Principal Global Opportunities } \\
\text { Fund(D) }\end{array}$ & 51.37 & 0.8977 & 0.6714 & 0.6714 & 0.5213 \\
\hline $\begin{array}{c}\text { Principal Global Opportunities } \\
\text { Fund(G) }\end{array}$ & 20.49 & 0.7862 & 0.6714 & 0.6714 & 0.5213 \\
\hline $\begin{array}{l}\text { Sensex ICICI Prudential Exchange } \\
\text { Traded Fund }\end{array}$ & 35.37 & 1.0102 & 0.5903 & 0.5903 & 0.4649 \\
\hline Kotak Sensex ETF & 58.38 & 1.0236 & 0.5794 & 0.5794 & 0.4593 \\
\hline $\begin{array}{c}\text { Gold Benchmark Exchange Traded } \\
\text { Scheme (Gold BeES) }\end{array}$ & 33.60 & 1.0752 & 0.5740 & 0.5740 & 0.4412 \\
\hline UTI Sunder & 35.37 & 1.0298 & 0.5733 & 0.5733 & 0.4654 \\
\hline $\begin{array}{l}\text { Reliance Gold Exchange Traded } \\
\text { Fund(D) }\end{array}$ & 35.36 & 1.0616 & 0.5711 & 0.5711 & 0.4380 \\
\hline Quantum Gold Fund (an ETF) & 57.87 & 0.9972 & 0.5678 & 0.5678 & 0.4377 \\
\hline $\begin{array}{l}\text { Nifty Benchmark Exchange Traded } \\
\text { Scheme- Nifty BeES }\end{array}$ & 35.44 & 0.9757 & 0.5468 & 0.5468 & 0.4442 \\
\hline Quantum Index Fund & 20.45 & 0.7902 & 0.5444 & 0.5444 & 0.4430 \\
\hline $\begin{array}{l}\text { Reliance Banking Exchange Traded } \\
\text { Fund(D) }\end{array}$ & 37.77 & 0.9141 & 0.5016 & 0.5016 & 0.4070 \\
\hline $\begin{array}{l}\text { Dws Global Thematic Offshore Fund } \\
\text { (D) }\end{array}$ & 19.87 & 0.6173 & 0.4898 & 0.4898 & 0.7660 \\
\hline $\begin{array}{c}\text { Dws Global Thematic Offshore } \\
\text { Fund(G) }\end{array}$ & 19.87 & 0.6173 & 0.4898 & 0.4898 & 0.8612 \\
\hline $\begin{array}{l}\text { Banking Index Benchmark Exchange } \\
\text { Traded Scheme (Bank BeES) }\end{array}$ & 56.92 & 0.9771 & 0.4804 & 0.4804 & 0.3899 \\
\hline Kotak PSU Bank ETF & 37.03 & 0.8995 & 0.4543 & 0.4543 & 0.3688 \\
\hline $\begin{array}{l}\text { Ft India Life Stage Fund Of Funds-The } \\
\text { 50+S Plan (D) }\end{array}$ & 16.38 & 1.0396 & 0.4537 & 0.4537 & 0.3975 \\
\hline
\end{tabular}


PSU Bank Benchmark Exchange

Traded Scheme (PSU Bank BeES)

ING Global Real Estate Fund - Retail Plan (D)

ING Global Real Estate Fund - Retail Plan (G)

DSP BlackRock World Gold

Fund-Regular Plan( G)

AIG World Gold Fund(G)

ING Global Real Estate

Fund-Institutional Plan (D)

ING Global Real Estate

Fund-Institutional Plan (G)

FT India Dynamic PE Ratio Fund of Funds(D)

AIG World Gold Fund(D)

ING OptiMix Asset Allocator

Multi-Manager FoF Scheme (G)

ING OptiMix Asset Allocator

Multi-Manager FoF Scheme (D)

DSP BlackRock World Gold Fund-Regular Plan (D)

$\begin{array}{lllll}37.02 & 0.8994 & 0.4395 & 0.4395 & 0.3579 \\ 38.94 & 0.5691 & 0.4236 & 0.4236 & 0.2722 \\ 38.93 & 0.5663 & 0.4221 & 0.4221 & 0.2714 \\ 29.62 & 0.7895 & 0.4203 & 0.4203 & 0.7479 \\ 36.97 & 0.8123 & 0.4170 & 0.4170 & 0.3261 \\ 26.79 & 0.5786 & 0.3906 & 0.3906 & 0.2646 \\ 26.75 & 0.6105 & 0.3898 & 0.3898 & 0.2715 \\ 19.22 & 0.4724 & 0.3806 & 0.3806 & 0.6680 \\ 31.05 & 0.6615 & 0.3542 & 0.3542 & 0.2753 \\ 32.38 & 0.2821 & 0.2740 & 0.2740 & 0.2311 \\ 32.35 & 0.2821 & 0.2740 & 0.2740 & 0.2311 \\ 19.52 & 0.2931 & 0.2402 & 0.2402 & 0.7070\end{array}$

The scheme names are abbreviated as follows: D indicates Dividend payout option; G indicates Growth Plans; FoF indicates Fund of funds.

Fund Type is abbreviated as follows: Pvt.(F) indicates foreign private Asset Management Companies(AMC) ; Pvt.(I) indicates private Indian AMC; Pvt. JV(I) indicates Private Joint Ventures-Predominantly Indian; Pvt. JV(F) indicates Private Joint Ventures-Predominantly Foreign.

The top 25 large ETFs based on total assets under management were selected and ranked to examine the relationship between fund size and efficiency. Table 8 presents the efficient scores of the top 25 large ETFs as on $1^{\text {st }}$ April 2011. The data used was the 12 months performance of these 25 funds. The most recent funds were the funds with the highest investment inflows. The efficiency scores indicate that the largest funds are not the most efficient funds. Funds found efficient across these 25 ETFs are the funds that provided highest returns and have higher Sharpe ratios. This infers that larger fund size does not indicate superior performance.

Table 8. Largest 25 Funds based on assets under management: efficiency scores

\begin{tabular}{cccccccc}
\hline Fund Name & $\begin{array}{c}\text { Annualized } \\
\text { Return }\end{array}$ & $\begin{array}{c}\text { Sharp e } \\
\text { Ratio }\end{array}$ & $\begin{array}{c}\text { Basic } \\
\text { Efficiency }\end{array}$ & $\begin{array}{c}\text { Super } \\
\text { Efficiency }\end{array}$ & $\begin{array}{c}\text { Mean Cross } \\
\text { Efficiency }\end{array}$ & $\begin{array}{c}\text { AUM (Rs in } \\
\text { lakhs) }\end{array}$ & $\begin{array}{c}\text { AMC } \\
\text { Category }\end{array}$ \\
\hline $\begin{array}{c}\text { HDFC Gold } \\
\text { Exchange } \\
\text { Traded Fund } \\
\text { DWS Global } \\
\text { Agribusiness }\end{array}$ & 24.9424 & 1.4452 & 1 & 1.0276 & 97.059 & 27801.45 & Pvt.(I) \\
$\begin{array}{c}\text { Fund-Regular } \\
\text { Plan(G) }\end{array}$ & 30.7096 & 1.7706 & 1 & 1 & 98.1746 & 14616.26 & Pvt. JV(I) \\
$\begin{array}{c}\text { DWS Global } \\
\text { Agribusiness }\end{array}$ & & & & & & \\
$\begin{array}{c}\text { Fund-Regular } \\
\text { Plan(D) }\end{array}$ & 30.7096 & 1.7706 & 1 & 1 & 98.1746 & 9612.347 & Pvt. JV(I) \\
$\begin{array}{l}\text { ICICI } \\
\text { Prudential } \\
\text { Gold ETF }\end{array}$ & 24.4944 & 1.4009 & 0.9936 & 0.9936 & 96.0004 & 8075.208 & \\
\hline
\end{tabular}




\begin{tabular}{|c|c|c|c|c|c|c|}
\hline \multicolumn{7}{|l|}{$\begin{array}{c}\text { JPMorgan JF } \\
\text { Greater }\end{array}$} \\
\hline $\begin{array}{c}\text { China Equity } \\
\text { Off-shore } \\
\text { Fund }\end{array}$ & 17.1910 & 0.6381 & 0.9761 & 0.9761 & 79.2511 & 7533.463 \\
\hline $\begin{array}{l}\text { ING OptiMix } \\
\text { Global } \\
\text { Commodities } \\
\text { Fund }(\mathrm{G})\end{array}$ & 25.4623 & 0.9485 & 0.9665 & 0.9665 & 80.2355 & 11319.25 \\
\hline $\begin{array}{l}\text { ING OptiMix } \\
\text { G3lobal } \\
\text { Commodities } \\
\text { Fund (D) }\end{array}$ & 25.4942 & 0.9504 & 0.9664 & 0.9664 & 80.1811 & 21362.61 \\
\hline $\begin{array}{c}\text { Axis Gold } \\
\text { ETF }\end{array}$ & 18.4110 & 0.8560 & 0.9619 & 0.9619 & 86.6206 & 13945.73 \\
\hline $\begin{array}{l}\text { SBI gold ETF } \\
\text { DSP Black }\end{array}$ & 22.6714 & 0.9193 & 0.9446 & 0.9446 & 80.9351 & 11021.97 \\
\hline $\begin{array}{l}\text { Rock World } \\
\text { Energy Fund } \\
\text { (G) }\end{array}$ & 28.9387 & 0.7531 & 0.8194 & 0.8194 & 62.6949 & 16532.72 \\
\hline $\begin{array}{l}\text { DSP Black } \\
\text { Rock World } \\
\text { Energy Fund } \\
\text { (D) }\end{array}$ & 24.2434 & 0.6749 & 0.8194 & 0.8194 & 62.6949 & 12226.44 \\
\hline $\begin{array}{c}\text { Fidelity } \\
\text { Global Real } \\
\text { Assets } \\
\text { Fund(G) }\end{array}$ & 24.8460 & 0.9656 & 0.7187 & 0.7187 & 63.0618 & 91849.78 \\
\hline $\begin{array}{c}\text { Fidelity } \\
\text { Global Real } \\
\text { Assets } \\
\text { Fund(D) }\end{array}$ & 24.8460 & 0.9656 & 0.7187 & 0.7187 & 63.0618 & 57249.46 \\
\hline $\begin{array}{l}\text { UTI Sunder } \\
\text { ETF }\end{array}$ & 15.5761 & 0.2397 & 0.7035 & 0.7035 & 51.0618 & 34421.57 \\
\hline $\begin{array}{c}\text { Reliance } \\
\text { Gold ETF(D) }\end{array}$ & 25.6827 & 0.7784 & 0.6531 & 0.6531 & 55.9365 & 21807.84 \\
\hline $\begin{array}{c}\text { Sundaram } \\
\text { Global } \\
\text { Advantage } \\
\text { Fund (G) }\end{array}$ & 8.6092 & 0.0321 & 0.5176 & 0.5176 & 37.7701 & 10861.66 \\
\hline $\begin{array}{l}\text { Sundaram } \\
\text { Global } \\
\text { Advantage } \\
\text { Fund (D) }\end{array}$ & 8.3780 & 0.0144 & 0.5176 & 0.5176 & 37.7699 & 7551.553 \\
\hline $\begin{array}{c}\text { DSP } \\
\text { BlackRock } \\
\text { World } \\
\text { Mining Fund } \\
\text { (G) }\end{array}$ & 13.4831 & 0.3230 & 0.4989 & 0.4989 & 40.7422 & 6045.717 \\
\hline $\begin{array}{l}\text { DSP Black } \\
\text { Rock World } \\
\text { Gold Fund } \\
\text { (G) }\end{array}$ & 28.9387 & 0.7531 & 0.4834 & 0.4834 & 37.3661 & 13251.69 \\
\hline
\end{tabular}




\begin{tabular}{ccccccc}
\hline $\begin{array}{c}\text { Nifty Junior } \\
\text { Benchmark }\end{array}$ & 18.9005 & 0.2619 & 0.4779 & 0.4779 & 35.8329 & 8606.91 \\
$\begin{array}{c}\text { ETF (Junior } \\
\text { BeES) }\end{array}$ & & & & & & \\
$\begin{array}{c}\text { Shariah BeES } \\
\text { Reliance } \\
\text { Banking }\end{array}$ & 31.8524 & 0.7915 & 0.4435 & 0.4435 & 32.8026 & 226980.7 \\
$\begin{array}{c}\text { ETFund-(D) } \\
\text { Kotak Sensex } \\
\quad \text { ETF }\end{array}$ & 11.9321 & 0.6868 & 0.37 & 0.37 & 29.1178 & 5479.576 \\
$\begin{array}{c}\text { PSU Bank } \\
\text { Benchmark } \\
\text { ET (PSU }\end{array}$ & 20.1548 & 0.2551 & 0.3046 & 0.3046 & 23.8601 & 21285.17 \\
Bank BeES) & & 0.2843 & 0.332 & 0.332 & 27.2671 & 31297.14 \\
$\begin{array}{c}\text { Kotak PSU } \\
\text { Bank ETF }\end{array}$ & 18.9316 & 0.2267 & 0.2995 & 0.2995 & 23.2469 & 4859.07 \\
\hline
\end{tabular}

Note: 25 large funds as on $1^{\text {st }}$ April 2010 were evaluated based on the performance of 12 months between April 2010 and March 2011

Table 9. Pearson's correlation between sharp ratios and basic efficiency scores

\section{Model Period of Study Correlation coefficient significance at the 0.01 level (2-tailed)}

\begin{tabular}{lllll}
\hline 1 & $2007-11$ & 0.1728 & 0.321 & 35 \\
2 & $2009-11$ & $0.608^{* *}$ & 0.000 & 67 \\
3 & $2010-11$ & $0.736^{* *}$ & 0.000 & 25 \\
\hline
\end{tabular}

$* 90 \%$ significance level, $* * 95 \%$ significance level, $* * * 99 \%$ significance level

\section{Conclusion}

This research paper evaluates the performance of all the 82 Exchange-Traded schemes floated and traded on the Indian Stock markets. The compounded growth rates across the years 2006-2011 and trend analysis reveals that the overseas fund of funds as well as the Gold funds were able to impress the investors and were able to mobilize greater resources. On an average, the ETFs grew at a compounded annual growth rate of $37 \%$ during 2006-11. It has been found that foreign AMCs were holding $55 \%$ of assets across the ETFs, followed by Indian Joint Ventures and Private AMCs. ETFs have consistently outperformed the market index and have generated higher returns. The volatility of their returns was also found to be lesser than that of the returns of the bench mark index NIFTY in equity market. On an average, the ETFs were able to generate $3 \%$ annualized excess returns over the market returns.

Assets under management reflect the investment flows and the resources mobilized by the fund. Investors would like to chase performance and invest in superior performing funds. The funds floated on the Indian equity market indices (categorized as other ETFs) grew substantially during the boom period of 2006-07. Overseas funds and Gold funds grew substantially during and after 2008, the post global financial crisis period. In addition to the contemporary economic conditions, these investment flows indicate investors' risk appetite, interest in the sector and their expectations about the performance of the fund.

Data Envelopment Analysis was used with three input and two output variables to capture the multidimensional nature of risk and return parameters. The funds found efficient by this model were not the funds giving highest return. However, the efficiency scores have a statistically significant correlation with the Sharpe ratios that were used widely to rank mutual funds. DEA ranking is not only based on excess returns to risk to return ratio as in case of Sharpe ratio, it is also more comprehensive as it includes multiple input and output variables and provides better fund evaluation.

DEA ranked the funds floated by foreign AMCs and AMCs with Joint Ventures as relatively efficient funds. Among the foreign AMCs, Franklin Templeton funds were found to be the efficient fund across all the years. Domestic funds were found to be efficient in not just the analysis of the 35 funds for 53 months but also in the 
analysis of the 67 funds for the 29 post financial crisis months beginning January 2009. The analysis of 25 large funds for the most recent 12 months period (April2010-11) identified overseas fund of fund and Gold ETF as superior funds. These efficient funds were also found to be giving highest returns and having higher Sharpe ratios. However, large funds holding maximum assets were found to be neither efficient nor did they provide the highest returns.

The growth and success of the fund industry requires the investors to choose superior funds rationally and requires the managers to deploy these funds efficiently to improve fund performance. Data Envelopment Analysis is an improved evaluation technique incorporating multiple parameters for the assessment of mutual funds.

\section{Acknowledgement}

The author acknowledges the research support received from the following intern students:

- $\quad$ Kishore Kumar, R., Undergraduate student in Department of Metallurgical and Materials Engineering, IIT Madras.

- $\quad$ Nitin, G., Undergraduate student in Department of Ocean Engineering, IIT Madras.

\section{References}

Adjei, F. (2009). Diversification, Performance, and Performance Persistence in Exchange-Traded Funds, International Review of Applied Financial Issues and Economics, 1(1).

Anderson, R. I., Brockman C. M., Giannakos, C., \& McLeod, R. W. (2004). A Non-Parametric Examination of Real Estate Mutual Fund Efficiency. International Journal of Business and Economics, 3(3), 225-38.

Blitz, D., \& Huij, J. (2011). Evaluating the Performance of Global Emerging Markets Equity Exchange-Traded Funds.

Blitz, D., Huij , J., \& Swinkels, L. (2009). The Performance of European Index Funds and Exchange-Traded Funds. http://dx.doi.org/10.2139/ssrn.1438484

Chang, C. E., \& Krueger, T. M. (2012). The Case for Country-specific Closed-end Funds Instead of Exchange-traded Funds. International Business Research, 5(5). http://dx.doi.org/10.5539/ibr.v5n5p3

Charupat, N., \& Miu, P. (2011). The pricing and performance of leveraged exchange-traded funds. Journal of Banking \& Finance, 35(4), 966-977. http://dx.doi.org/10.1016/j.jbankfin.2010.09.012

Ching-Chung, L., Shih-Ju, C., \& Hsinan, H. (2005). Pricing efficiency of exchange traded funds in Taiwan. Journal of Asset Management, 7(1), 60-68.

Gerasimos, G., \& Rompotis. (2011) Does premium impact Exchange-Traded Funds' returns? Journal of Asset Management, 11, 298-308.

Gerasimos, G., \& Rompotis.(2011). Predictable patterns in ETFs' return and tracking error. Studies in Economics and Finance, 28(1).

Greg, N., \& Gregoriou (2006). Optimization of Largest US Mutual Funds using Data Envelopment Analysis. Journal of Asset Management, 6(6), 445-55. http://dx.doi.org/10.1057/palgrave.jam.2240194

Houweling, P. (2012). On the Performance of Fixed Income Exchange Traded Funds. The Journal of Index Investing, 3(1), 39-44. http://dx.doi.org/10.3905/jii.2012.3.1.039

Huang, H., Jennifer, C., \& Gued, L. (2009). Are ETFs Replacing Index Mutual Funds? AFA 2009 San Francisco Meetings Paper. http://dx.doi.org/10.2139/ssrn.1108728

Ioannis, E., \& Tsolas. (2011). Natural Resources Exchange Traded Funds: Performance Appraisal using DEA Modeling. Journal of Centrum Cathedra, 4(2), 250-259.

Jack, W., Aber, Dan, L., \& Luc, C. (2009). Price volatility and tracking ability of ETFs. Journal of Asset Management, 10, 210-221. http://dx.doi.org/10.1057/jam.2009.13

Jaspal, S. (2004). Growth, Performance and Prospects of Mutual Funds in India. Finance India, 18(4), $1755-1760$.

Joel, T., Harper, A., Jeff, M., \& Oliver, S. (2006). Performance comparison between exchange-traded funds and closed-end country funds. International Financial Markets, Institution and Money, 16(2), 104-122. http://dx.doi.org/10.1016/j.intfin.2004.12.006 
Johnson, \& William, F. (2009). Tracking errors of exchange traded funds. Journal of Asset Management, 10(4), 253-262. http://dx.doi.org/10.1057/jam.2009.10

Madhumita Chakraborty, P., Jain, K., \& Vinay, K. (2008). Mutual funds performance: An evaluation of select growth funds in India. South Asian Journal of Management, 80(4), 80-92.

Meric, I., McCall Charles, W., \& Meric, G. (2009). Performance of exchange-traded sector index funds in the October 9, 2007-March 9, 2009 bear market ,Rowan University Journal of Finance and Accountancy.

Patrick Kuok-Kun Chu. (2011). Study on the tracking errors and their determinants: evidence from Hong Kong exchange traded funds. Applied Financial Economics, 21(5), 309-315. http://dx.doi.org/10.1080/09603107.2010.530215

Sedzro, K. T., \& Sardano, D. (2000). Mutual Fund Performance Evaluation Using Data Envelopment Analysis. In S. B. Dahiya (ed.) The current state of business disciplines, Spellbound Publications, Rohtak, India, $1125-44$.

Sivakumar, K. P., Rajmohan, S., Sezhiyan, D. M., \& Narasimhulu, S. (2010). Performance Evaluation of Mutual Fund Industry in India. Vidwat:The Indian Journal of Management, 3(1), 26-32.

William, F., \& Johnson. (2009). Tracking errors of exchange traded funds. Journal of Asset Management, 10, 253-262. http://dx.doi.org/10.1057/jam.2009.10

Wong Karen, H. Y., \& Shum Wai, C. (2010). Exchange-traded funds in bullish and bearish markets. Applied Economics Letters, 17, 1615-1624. http://dx.doi.org/10.1080/13504850903085035

Yuexiang, J., \& Feng, G., \& Tianjian, L. (2010). Pricing Efficiency of China's Exchange-Traded Fund Market. Chinese Economy, 43(5), 32-49. http://dx.doi.org/10.2753/CES1097-1475430503

\section{Annexure}

Table 10. AUM details

\begin{tabular}{ccccc}
\hline S.No. & Month & Total & ETF & ETF/Total \\
\hline 1 & Apr-06 & 12502774.95 & 141976.55 & $1.14 \%$ \\
2 & May-06 & 13870447.37 & 141026.72 & $1.02 \%$ \\
3 & Jun-06 & 15099569.01 & 134929.03 & $0.89 \%$ \\
4 & Jul-06 & 15549869.21 & 149466.34 & $0.96 \%$ \\
5 & Aug-06 & 29856274.62 & 323712.44 & $1.08 \%$ \\
6 & Sep-06 & 30368553.96 & 538691.04 & $1.77 \%$ \\
7 & Oct-06 & 30734844 & 770483.15 & $2.51 \%$ \\
8 & Nov-06 & 32573585.23 & 1111196.55 & $3.41 \%$ \\
9 & Dec-06 & 33446861.78 & 1043521.56 & $3.12 \%$ \\
10 & Jan-07 & 33712307.52 & 893654.36 & $2.65 \%$ \\
11 & Feb-07 & 35537786.74 & 768438 & $2.16 \%$ \\
12 & Mar-07 & 35573949.09 & 642874.27 & $1.81 \%$ \\
13 & Apr-07 & 35550860.97 & 724175.91 & $2.04 \%$ \\
14 & May-07 & 38480021.42 & 916822.24 & $2.38 \%$ \\
15 & Jun-07 & 42494747.22 & 993482.51 & $2.34 \%$ \\
16 & Jul-07 & 46356771.03 & 987023.26 & $2.13 \%$ \\
17 & Aug-07 & 47047102.57 & 818719.77 & $1.74 \%$ \\
18 & Sep-07 & 48023497.99 & 996808.23 & $2.08 \%$ \\
19 & Oct-07 & 53139165.72 & 1226942.06 & $2.31 \%$ \\
20 & Nov-07 & 54738634.33 & 1156278.74 & $2.11 \%$ \\
21 & Dec-07 & 54928107.55 & 1172331.34 & $2.13 \%$ \\
22 & Jan-08 & 57298531.39 & 1022451.02 & $1.78 \%$ \\
23 & Feb-08 & 56759005.05 & 941200.34 & $1.66 \%$ \\
24 & Mar-08 & 53103545.62 & 773642.69 & $1.46 \%$ \\
25 & Apr-08 & 56949424.11 & 730255.9 & $1.28 \%$ \\
26 & May-08 & 60014118.48 & 736472.62 & $1.23 \%$ \\
\hline
\end{tabular}




\begin{tabular}{|c|c|c|c|c|}
\hline 27 & Jun-08 & 56446946.54 & 726858.58 & $1.29 \%$ \\
\hline 28 & Jul-08 & 52913188.33 & 752628.22 & $1.42 \%$ \\
\hline 29 & Aug-08 & 54367876.33 & 825510.23 & $1.52 \%$ \\
\hline 30 & Sep-08 & 52722480.99 & 811390.82 & $1.54 \%$ \\
\hline 31 & Oct-08 & 42993021.15 & 685196.73 & $1.59 \%$ \\
\hline 32 & Nov-08 & 40011658.62 & 596388.8 & $1.49 \%$ \\
\hline 33 & Dec-08 & 41925417.89 & 578588.52 & $1.38 \%$ \\
\hline 34 & Jan-09 & 45906617.12 & 553505.31 & $1.21 \%$ \\
\hline 35 & Feb-09 & 49912176.12 & 521084.48 & $1.04 \%$ \\
\hline 36 & Mar-09 & 49150471.75 & 480916.19 & $0.98 \%$ \\
\hline 37 & Apr-09 & 54949233.39 & 458343.78 & $0.83 \%$ \\
\hline 38 & May-09 & 63756988.84 & 492179.26 & $0.77 \%$ \\
\hline 39 & Jun-09 & 66948445.12 & 503385.31 & $0.75 \%$ \\
\hline 40 & Jul-09 & 68863177.49 & 499701.26 & $0.73 \%$ \\
\hline 41 & Aug-09 & 74873346.89 & 523805.03 & $0.70 \%$ \\
\hline 42 & Sep-09 & 74285215.58 & 575902.86 & $0.78 \%$ \\
\hline 43 & Oct-09 & 76282366.23 & 476006.69 & $0.62 \%$ \\
\hline 44 & Nov-09 & 80808613.21 & 511659.39 & $0.63 \%$ \\
\hline 45 & Dec-09 & 79520999.52 & 630163.69 & $0.79 \%$ \\
\hline 46 & Jan-10 & 76235438.09 & 635823.8 & $0.83 \%$ \\
\hline 47 & Feb-10 & 78254591.46 & 669059.59 & $0.85 \%$ \\
\hline 48 & Mar-10 & 74859247.78 & 677956.26 & $0.91 \%$ \\
\hline 49 & Apr-10 & 77048071.12 & 689713.36 & $0.90 \%$ \\
\hline 50 & May-10 & 80501879.98 & 731515.17 & $0.91 \%$ \\
\hline 51 & Jun-10 & 67739904.67 & 737149.26 & $1.09 \%$ \\
\hline 52 & Jul-10 & 66720624.85 & 732314.61 & $1.10 \%$ \\
\hline 53 & Aug-10 & 68932471.39 & 766021.94 & $1.11 \%$ \\
\hline 54 & Sep-10 & 71526379.45 & 837314.66 & $1.17 \%$ \\
\hline 55 & Oct-10 & 67806744.31 & 971248.56 & $1.43 \%$ \\
\hline 56 & Nov-10 & 67806744.31 & 971248.56 & $1.43 \%$ \\
\hline 57 & Dec-10 & 67806744.31 & 971248.56 & $1.43 \%$ \\
\hline
\end{tabular}

